\title{
Optimasi Kondisi Pengeringan Mie Singkong dengan Response Surface Methodology Terhadap Karakteristik Produknya
}

\author{
Optimization Drying Conditions of Cassava Noodles Using Response Surface Methodology \\ on Its Product Characteristics
}

\author{
Henny Krissetiana Hendrasty, Sundari Setyaningsih*, Raden Sugiarto \\ Fakultas Teknologi Pertanian, Institut Pertanian (INTAN) Yogyakarta \\ Jl. Magelang, Km 5,6 Yogyakarta, Indonesia \\ *Email: ndarisetya@yahoo.com
}

Tanggal submisi: 13 Januari 2019; Tanggal penerimaan: 14 Mei 2019

\begin{abstract}
ABSTRAK
Mie singkong basah sudah berkembang di Desa Srihardono, Kecamatan Pundong, Bantul. Kelemahan mie singkong basah adalah umur simpan pendek. Penelitian ini bertujuan untuk menentukan kondisi optimum proses pengeringan sehingga diperoleh mutu mie singkong kering yang terbaik. Faktor yang diteliti adalah suhu dan lama pengeringan serta tebal lapisan mie. Bahan mie singkong kering adalah kombinasi dari pati yang dibuat secara tradisional dan pabrik (pabrikan). Perbandingan pati tradisional dan pati pabrikan adalah 3:2. Pengeringan dilakukan menggunakan Cabinet drier dengan variasi suhu 70, 80 dan $90{ }^{\circ} \mathrm{C}$ dengan variasi lama pengeringan 2 jam, 2,5 jam, 3 jam, 3,5 jam dan 4 jam. Selama pengeringan, mie disusun dalam 1 lapis, 2 lapis, 3 lapis dan 4 lapis. Parameter mutu yang diamati adalah elongasi, kadar air mie kering, cooking loss dan daya serap air. Data yang diperoleh dianalisis menggunakan Respons Surface Methodology. Hasil menunjukkan bahwa kisaran kondisi optimum pengeringan adalah pada suhu $76-84^{\circ} \mathrm{C}$ selama 3,2-3,5 jam dan mie disusun 2 lapis. Mie singkong kering mempunyai nilai elongasi $60-70 \%$, kadar air $8-9 \%$, cooking loss $10-12 \%$ dan daya serap air $140-150 \%$.
\end{abstract}

Kata kunci: Mie singkong kering; cooking loss; pengeringan; elongasi; daya serap

\begin{abstract}
Wet cassava starch noodles have been developed in Srihardono Village, Pundong-Bantul District. The disadvantage of this noodle is the short shelf life. The objective of this study was to determine the optimum drying conditions to obtain the best quality of dried cassava noodles. The factors, such as temperature and drying time, and noodle layer were evaluated. Dried cassava noodles contain a combination of traditionally processed cassava starch and manufactured cassava starch. The ratio of traditional starch to manufactured starch was 3:2 (w/w). Drying was conducted using a cabinet drier at various temperatures $\left(70,80\right.$ and $\left.90^{\circ} \mathrm{C}\right)$ for $2 \mathrm{~h}, 2.5 \mathrm{~h}, 3 \mathrm{~h}, 3.5 \mathrm{~h}$ and 4 h. Noodle layers were 1, 2, 3 and 4. The observed quality parameters were elongation, water content, cooking loss and water absorption. The obtained data were analyzed using a Response Surface Methodology. The range of optimum drying condition was between 76 and $84^{\circ} \mathrm{C}$ and drying time between 3.2 and $3.5 \mathrm{~h}$. Noodles were arranged in 2 layers. Dried cassava noodles had an elongation value of 60 to $70 \%$, water content of 8 to $9 \%$, cooking loss of 10 to $12 \%$ and water absorption of 140 to $150 \%$.
\end{abstract}

Keywords: Cassava starch noodles; cooking loss; drying; elongation; water absorption 


\section{PENDAHULUAN}

Mie adalah salah satu produk pangan yang sangat popular dan banyak digemari oleh berbagai kalangan masyarakat. Produk ini pada umumnya dibuat dari terigu. Penggunaan tepung pengganti terigu akan sangat diharapkan dapat mengurangi devisa negara. Untuk mengurangi impor perlu dicari bahan yang dapat digunakan untuk menggantikan terigu, salah satunya adalah tepung singkong (Indrianti dkk., 2015; Omeire dkk.,2015). Pembuatan mie dari bahan baku non terigu berbeda dengan pembuatan mie terigu. Mie yang dibuat dari tepung non terigu mengandalkan proses gelatinisasi dan mekanisme retrogradasi untuk membentuk jaringan struktur mie yang kokoh.

Mie basah umur simpannya sangat terbatas. Alternatif untuk memperpanjang umur simpannya adalah dengan pembekuan (Liu dkk., 2019; Lü dkk., 2014) dan kombinasi perlakuan ozone dan modified atmosphere packaging (Bai dkk., 2017). Kendalanya adalah penyimpanan beku biayanya mahal. Selain itu, pembekuan mie dapat menurunkan kekerasan mie dan absorpsi air serta meningkatkan cooking loss.

Pada umumnya, untuk meningkatkan umur simpannya maka dilakukan proses pengeringan (Piwińska dkk, 2016; Yu dkk., 2018; D'Amico dkk., 2015). Kondisi pengeringan mie berperan penting terhadap kualitas mie kering. Pengeringan biasanya dilakukan pada suhu rendah $\left(40-50{ }^{\circ} \mathrm{C}\right)$ dengan waktu yang relatif lama. Pengeringan pada suhu rendah dengan waktu lama dapat menyebabkan pertumbuhan mikrobia selama proses pengeringan. Salah satu alternatif penyelesaiannya adalah pengeringan pada suhu tinggi.

Daya serap air, cooking loss dan elongasi merupakan parameter mutu yang sangat penting pada produk mie. Parameter mutu ini sangat dipengaruhi oleh proses pengeringan (Piwińska dkk., 2016; D'Amico dkk., 2015; Petitot dkk., 2010; Jeong dkk., 2017; Kang dkk., 2018). Parameter mutu penting lainnya adalah kadar air, karena kadar air akan menentukan masa simpan produk. Berdasarkan standar SNI, kadar air mie kering adalah $7 \mathrm{~s} / \mathrm{d} 8$ persen. Oleh karena itu, pada penelitian ini bertujuan untuk menentukan kondisi pengeringan mie kering (suhu, waktu dan tebal lapisan) yang dioptimasi menggunakan Response Surface Methodology agar diperoleh kadar air mie kering sesuai dengan SNI dengan memperhatikan cooking loss, daya serap air, dan elongasi.

\section{METODE PENELITIAN}

\section{Bahan}

Penelitian ini menggunakan bahan pati singkong produksi pabrik yang dibeli dari PT Sinar Pematang Mulia dan pati singkong tradisional (produksi UKM) diperoleh dari UKM milik Bapak Mediharjo, Bantul.

\section{Pembuatan Mie Singkong}

Mie singkong dibuat dengan mencampur pati pabrik, pati tradisional dan air panas suhu $98{ }^{\circ} \mathrm{C}$ dengan rasio 375:250:525 (b/b/v). Campuran diaduk menggunakan mixer merk Boss (buatan Jerman) dengan kecepatan $200 \mathrm{rpm}$ selama 3 menit sehingga terbentuk adonan mie singkong. Adonan didinginkan sampai suhu 32- 34 ${ }^{\circ} \mathrm{C}$, kemudian dipipihkan dan dicetak dengan ukuran lebar $3 \mathrm{~mm}$.

\section{Pengaruh Pengeringan Mie terhadap Kadar Air, Cooking Loss, Daya Serap Air dan Elongasi}

Mie singkong dikeringkan dalam Cabinet drier dengan variasi suhu $50,60,70,80$ dan $90^{\circ} \mathrm{C}$. Sedangkan lama pengeringan adalah 2 jam, 2,5 jam, 3 jam, 3,5 jam dan 4 jam. Selama pengeringan mie disusun 1 lapis, 2 lapis, 3 lapis, 4 lapis. Selanjutnya produk mie kering diuji kadar air, elongasi, daya serap air dan cooking loss. Percobaan dilakukan 2 kali ulangan. Masing-masing parameter mutu diuji 3 kali ulangan.

\section{Analisa Kadar air dengan Metode Pemanasan (AOAC, 2005)}

Pati singkong sebanyak $2 \mathrm{~g}$ ditimbang dalam botol timbang yang sudah diketahui beratnya. Sampel selanjutnya dikeringkan dalam oven pada suhu 105 ${ }^{\circ} \mathrm{C}$ selama $3 \mathrm{~s} / \mathrm{d} 5$ jam. Selanjutnya didinginkan dalam eksikator dan ditimbang. Selanjutnya dipanaskan lagi dalam oven selama 30 menit, didinginkan dalam eksikator dan ditimbang. Perlakuan diulangi sampai tercapai berat konstan (selisih penimbangan berturutturut kurang dari 0,2 mg). Pengurangan berat merupakan banyaknya air dalam bahan.

$$
\text { Kadar air }=\frac{w_{0}-w_{1}}{w_{0}} * 100 \%
$$

$\mathrm{W}_{0}$ : berat awal sampel $(\mathrm{g}), \mathrm{w}_{1}$ : berat akhir sampel $(\mathrm{g})$

\section{Analisis Elongasi (Inglet dkk., 2005)}

Analisis elongasi menggunakan Texture Analyzer (TXT 32). Sampel (1 untai mie) dililitkan pada probe dengan jarak antar probe sebesar $2 \mathrm{~cm}$. Mie ditarik dengan kecepatan probe $0,3 \mathrm{~cm} /$ detik sampai putus. Persen elongasi dihitung dengan rumus: 


$$
\text { Elongasi }(\%)=\frac{t * v}{d} 100 \%
$$

dimana t: waktu putus (s), v: kecepatan probe $(\mathrm{cm} / \mathrm{s})$ dan d: jarak probe $(\mathrm{cm})$

\section{Analisis Daya Serap Air (AACC , 2000)}

Sampel mie mentah ( $5 \mathrm{~g}$ ) dimasukkan ke dalam air mendidih $100 \mathrm{~mL}$, lalu ditutup, dan dimasak sampai mie tergelatinisasi sempurna (3 menit ). Mie basah ditiriskan selama 5 menit, kemudian mie yang telah masak sempurna ditimbang. Penyerapan air diukur berdasarkan perubahan sebelum dan sesudah pemasakan.

$$
\text { Daya serap air }=\frac{\text { Berat sampel masak }}{\text { Berat sampel mentah }} * 100 \%
$$

\section{Analisis Cooking Loss}

Penentuan cooking loss dilakukan dengan metode Li dan Vasanthan (2003) yang telah dimodifikasi. Sebanyak $5 \mathrm{~g}$ mie direbus dalam $150 \mathrm{~mL}$ air selama 3 menit lalu ditiriskan. Kemudian mie dikeringkan pada suhu $100{ }^{\circ} \mathrm{C}$ hingga beratnya konstan, lalu ditimbang kembali. Mie yang lain sebanyak $5 \mathrm{~g}$ diukur kadar airnya (data kadar air digunakan untuk menghitung berat kering sampel). Cooking loss dihitung dengan Persamaan 4.

$$
\text { Cooking loss }=\frac{a-b}{a} * 100 \%
$$

Keterangan : $a=$ Berat kering sampel sebelum direbus $b=$ Berat kering sampel sesudah direbus

\section{Optimasi Kondisi Pengeringan}

Optimasi kondisi pengeringan dilakukan menggunakan metode Response Surface Methodology menggunakan disain Box Benken. Pengaruh kondisi pengeringan terhadap kadar air digunakan untuk menentukan titik $-1,0$ dan +1 . Optimasi kondisi pengeringan dilakukan menggunakan metode RSM dengan target utama kadar air dengan memperhatikan target lainnya antara lain cooking loss, daya serap air, dan elongasi. Oleh karena itu, gambar yang ditampilkan adalah overlay dari semua target tersebut.

\section{HASIL DAN PEMBAHASAN}

\section{Pengaruh Lama Pengeringan Terhadap Kadar Air Mie Kering}

Kadar air merupakan parameter mutu yang sangat penting pada produk kering, karena akan menentukan masa simpan produk. Gambar 1 terlihat bahwa kadar air turun dengan cepat pada periode awal pengeringan yaitu dari 0 ke 2 jam. Penurunan kadar air melambat dengan peningkatan lama pengeringan dari 2 jam ke 4 jam.

Semakin lama waktu pengeringan, air yang diuapkan dari bahan semakin sedikit. Hal ini disebabkan, pada fase awal masih terdapat jumlah air bebas yang banyak sehingga mudah untuk diuapkan. Semakin lama waktu pengeringan, air yang di permukaan telah seluruhnya diuapkan sehingga air dari dalam mie membutuhkan waktu untuk berdifusi lebih dahulu ke permukaan. Ada 3 jenis ikatan air dalam bahan pangan, yaitu air terikat kuat, air terikat lemah dan air bebas (Yu dkk., 2018). Periode kecepatan ini disebut periode kecepatan pengeringan menurun (falling rate period) (Demiray dan Tulek, 2014; Ogawa dkk., 2012). Periode kecepatan pengeringan menurun terjadi setelah kadar air bahan berada dibawah nilai kadar air (critical moisture content). Kecepatan pengeringan menurun terdiri atas pergerakan air dari dalam bahan ke permukaan dan penguapan air dari permukaan (Yu dkk., 2018). Semakin lama waktu pengeringan, jumlah air bebas yang diuapkan semakin banyak sehingga kadar air pada mie semakin rendah. Berdasarkan standar SNI, kadar air mie kering adalah $7 \mathrm{~s} / \mathrm{d} 8 \%$. Pada penelitian ini kadar air mie kering yang masuk standar SNI adalah pada lama pengeringan 3 jam, 3,5 jam dan 4 jam sehingga lama waktu tersebut dipilih sebagai titik -1 , 0 dan 1 pada optimasi kondisi pengeringan menggunakan Response Surface Methodology (RSM). Pada kondisi tersebut nilai elongasi sebesar $43,346 \%, 52,413 \%$ dan $33,184 \%$, cooking loss $15,958 \%, 15,436 \%$ dan $15,438 \%$, daya serap air $148,049 \%, 146,212 \%$ dan $145,123 \%$.

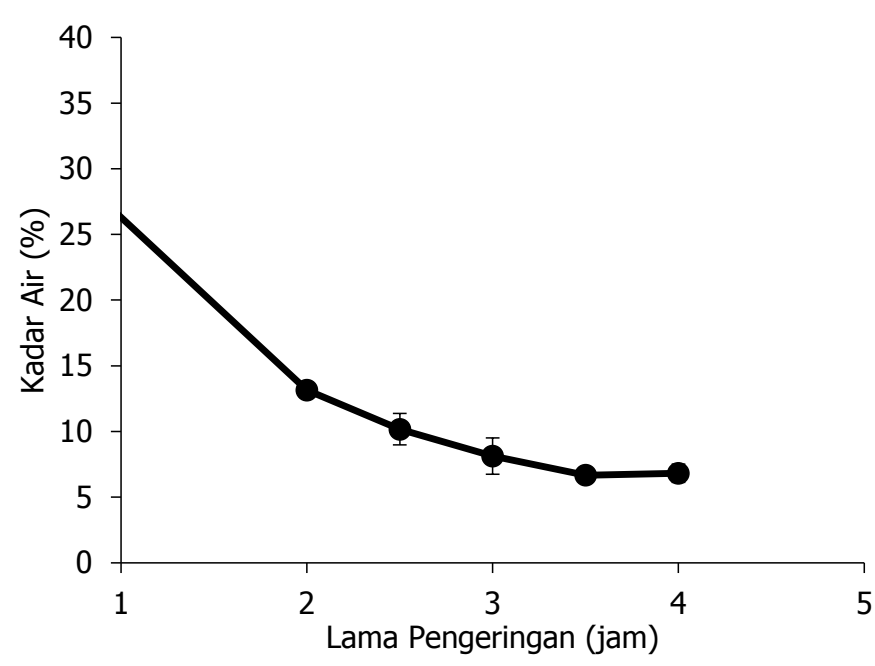

Gambar 1. Pengaruh lama pengeringan mie terhadap kadar air mie kering. Kadar air awal mie adalah $39,8 \%$, suhu pengeringan $80{ }^{\circ} \mathrm{C}$ dan jumlah lapisan hamparan adalah 4. 


\section{Pengaruh Suhu Pengeringan Terhadap Kadar Air Mie Kering}

Gambar 2 menunjukkan bahwa kadar air mie turun dengan kenaikan suhu pengeringan dari 50 ke $90{ }^{\circ} \mathrm{C}$. Hal ini disebabkan semakin besar perbedaan suhu antara medium pemanas dengan bahan pangan, semakin cepat pemindahan panas ke dalam bahan dan makin cepat pula penghilangan air dari bahan, sehingga waktu pengeringan akan semakin singkat (Mamat dkk., 2016). Suhu udara yang tinggi dapat menampung lebih banyak uap air pada proses pengeringan sebelum terjadi kejenuhan. Hal ini juga terjadi pada pengeringan mi beras, semakin tinggi suhu yang digunakan, semakin efektif pengurangan kadar air (Kongkiattisak dan Songsermpong, 2012). De Temmerman dkk. (2006) melaporkan pada penelitian pengeringan pasta semolina, semakin tinggi suhu pengeringan, kadar air bahan akan menurun semakin cepat. Waktu pengeringan semakin singkat karena air dari dalam bahan lebih cepat menguap menuju udara pengering di sekitar bahan. Berdasarkan SNI mie kering maka pengeringan pada suhu 70,80 dan $90^{\circ} \mathrm{C}$ telah memenuhi standar SNI mie kering sehingga suhu tersebut dipilih sebagai titik $-1,0$ dan 1 pada optimasi kondisi pengeringan menggunakan Response Surface Methodology (RSM). Pada suhu tersebut nilai elongasi sebesar $22,457 \%, 33,847 \%$ dan $30,823 \%$, cooking loss $8,15 \%, 11,31 \%$ dan $16,18 \%$, daya serap air $152,159 \%, 151,839 \%$ dan $161,791 \%$.

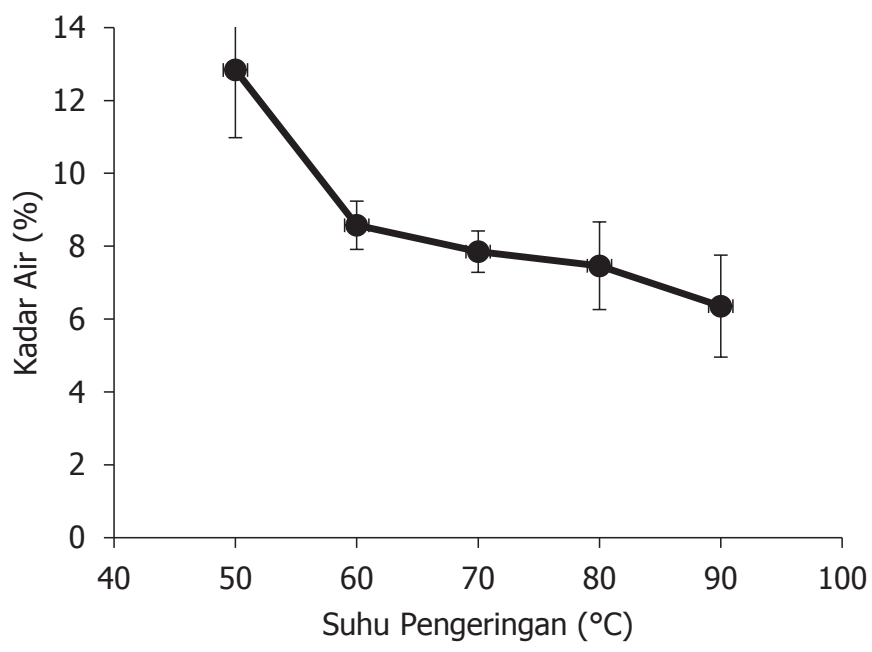

Gambar 2. Pengaruh suhu pengeringan mie terhadap kadar air mie kering. Kadar air awal mie adalah $39,8 \%$, lama pengeringan pengeringan 3,5 jam dan jumlah lapisan hamparan adalah 4 lapis

\section{Pengaruh Jumlah Lapisan Hamparan Terhadap Kadar Air Mie Kering}

Jumlah lapisan hamparan mie menentukan kecepatan pengeringan. Hal ini menyebabkan ketebalan produk meningkat dengan peningkatan jumlah lapisan. Ketebalan lapisan 1, 2, 3, 4 dan 5 masing-masing adalah 2, 4, 6, 8 dan $10 \mathrm{~mm}$. Gambar 3 menunjukkan bahwa peningkatan jumlah lapisan dari 2 ke 3 tidak menghasilkan kadar air yang berbeda secara signifikan. Peningkatan jumlah lapisan dari 3 ke 5 meningkatkan kadar air mie kering. Hal ini disebabkan sifat internal bahan seperti kadar air, ketebalan, struktur mikro pori-pori bahan, dan konduktifitas panas bahan menentukan transfer perpindahan air internal sehingga mempengaruhi kecepatan pengeringan (Ezeanya dkk., 2016). Jumlah lapisan 1-3 lapis mempunyai kadar air sesuai dengan SNI sehingga pengeringan pada 1, 2 dan 3 lapis dipilih sebagai titik $-1,0$ dan 1 pada optimasi kondisi pengeringan menggunakan Response Surface Methodology (RSM). Pada kondisi tersebut nilai elongasi sebesar $28,692 \%, 37,827 \%$ dan 34,669\%, cooking loss $17,462 \%, 13,757 \%$ dan $8,154 \%$, daya serap air $143,278 \%, 142,796 \%$ dan $143,031 \%$.

\section{Optimasi Kondisi Pengeringan terhadap Kadar Air, Cooking Loss, Daya Serap Air dan Elongasi}

Kadar air merupakan parameter mutu yang sangat penting pada produk kering, karena akan menentukan masa simpan produk. Parameter mutu lain pada produk mie kering adalah cooking loss, daya serap air dan

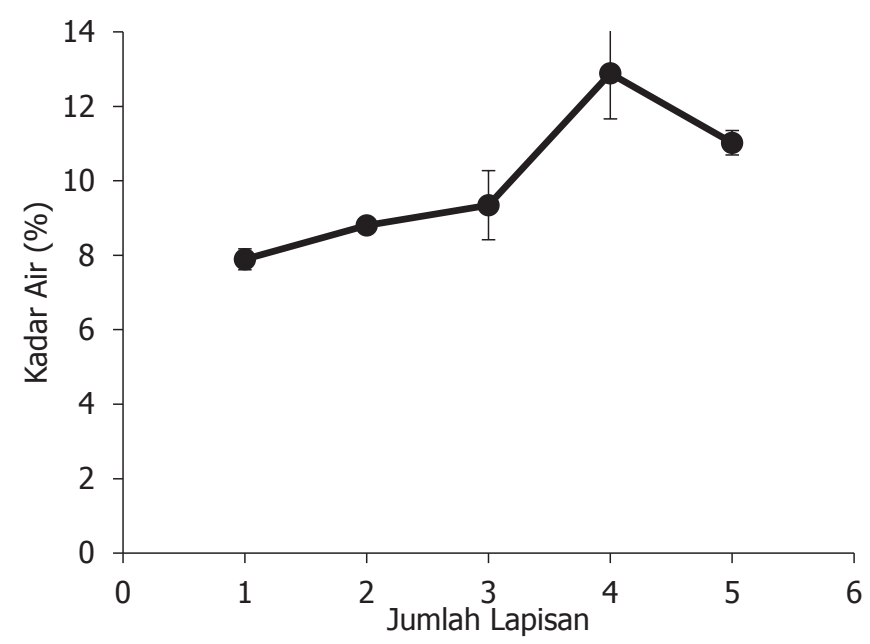

Gambar 3. Pengaruh jumalah lapisan hamparan mie terhadap kadar air mie kering. Kadar air awal mie adalah $39,8 \%$, suhu pengeringan adalah $80^{\circ} \mathrm{C}$ dan lama pengeringan adalah 3,5 jam 
H.K. Hendrasty dkk. /Agritech 39 (2) 2019 153-159

Tabel 1. Disain eksperimen optimasi kondisi pengeringan menggunakan Response Surface Methodology

\begin{tabular}{|c|c|c|c|c|c|c|c|c|c|}
\hline \multicolumn{2}{|c|}{$\begin{array}{l}\text { Variabel } \\
\text { Terkode }\end{array}$} & \multirow[b]{2}{*}{ X3 } & \multicolumn{3}{|c|}{ Variabel Sebenarnya } & \multicolumn{4}{|c|}{ Hasil } \\
\hline $\mathrm{X} 1$ & $\mathrm{X} 2$ & & $\mathrm{X} 1$ & $\mathrm{X} 2$ & $\mathrm{X} 3$ & Elongasi & Kadar Air & Cooking Loss & Daya Serap Air \\
\hline-1 & 0 & -1 & 70 & 3,5 & 1 & 60,8 & 7,4 & 14,2 & 146,5 \\
\hline 0 & 1 & -1 & 80 & 4 & 1 & 52,6 & 7,6 & 10,6 & 148,2 \\
\hline-1 & 1 & 0 & 70 & 4 & 2 & 45,9 & 7,4 & 12,3 & 146,6 \\
\hline 0 & 0 & 0 & 80 & 3,5 & 2 & 62,2 & 8,7 & 11,0 & 147,5 \\
\hline-1 & 0 & 1 & 70 & 3,5 & 3 & 49,8 & 11,7 & 10,0 & 147,4 \\
\hline 1 & 0 & -1 & 90 & 3,5 & 1 & 53,0 & 6,9 & 10,0 & 157,2 \\
\hline 1 & 0 & 1 & 90 & 3,5 & 3 & 44,2 & 7,9 & 12,1 & 150,6 \\
\hline 0 & -1 & 1 & 80 & 3 & 3 & 37,8 & 10,8 & 14,0 & 152,6 \\
\hline 0 & 0 & 0 & 80 & 3,5 & 2 & 64,6 & 8,7 & 11,0 & 147,5 \\
\hline 1 & 1 & 0 & 90 & 4 & 2 & 58,8 & 7,5 & 7,4 & 147,3 \\
\hline-1 & -1 & 0 & 70 & 3 & 2 & 60,3 & 11,2 & 13,0 & 143,2 \\
\hline 1 & -1 & 0 & 90 & 3 & 2 & 60,0 & 10,6 & 8,3 & 151,7 \\
\hline 0 & -1 & -1 & 80 & 3 & 1 & 57,7 & 8,2 & 12,4 & 154,9 \\
\hline
\end{tabular}

elongasi. Oleh karena itu, optimasi kondisi pengeringan juga melibatkan 4 faktor tersebut. Tabel 1 adalah disain eksperimen berdasarkan Box Benken dengan variable bebasnya adalah suhu pengeringan, lama pengeringan dan jumlah lapisan mie. Sedangkan target optimasi adalah kadar air, cooking loss, daya serap air dan elongasi.

\section{Optimasi Kondisi Pengeringan pada Jumlah Lapisan Konstan}

Kadar air dan cooking loss menurun dengan peningkatan suhu pengeringan (Gambar 4). Penurunan cooking loss kemungkinan disebabkan reorganisasi struktur kristal granula pati pada pengeringan suhu tinggi sehingga berpengaruh pada gelatinisasi granula
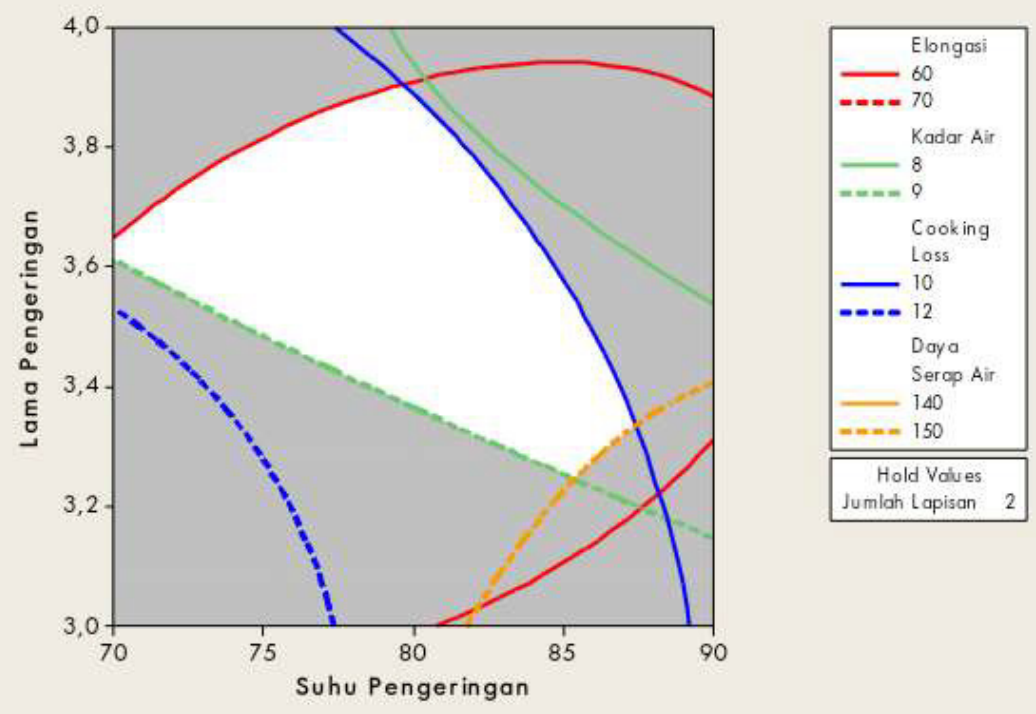

Gambar 4. Contour plot hubungan antara suhu pengeringan dengan lama pengeringan terhadap elongasi, kadar air, cooking loss dan daya serap air mie kering. 


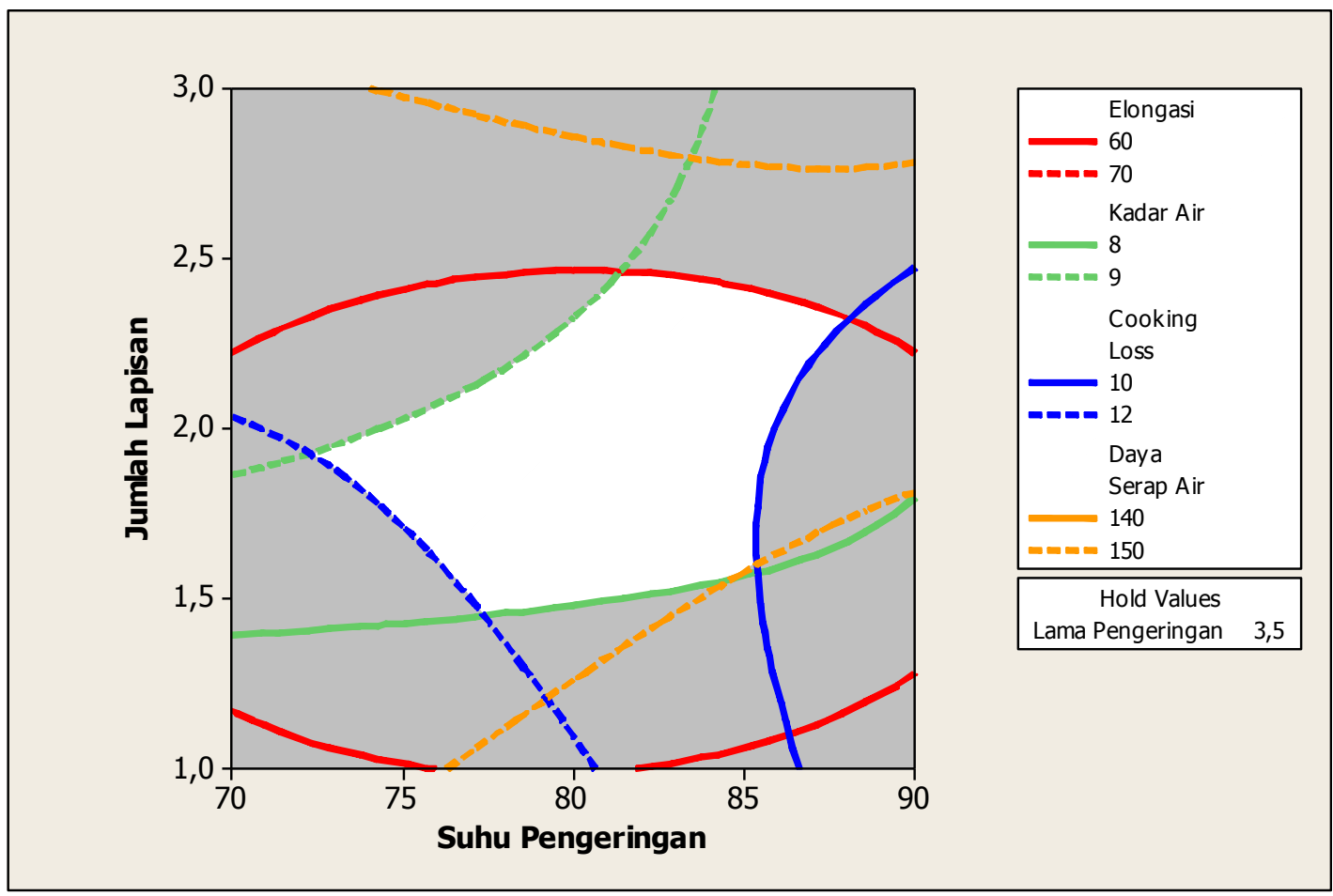

Gambar 5. Contour plot hubungan antara suhu pengeringan dengan jumlah lapisan terhadap elongasi, kadar air, cooking loss dan daya serap air mie kering.

pati (Zhang dkk., 2013). Elongasi mie kering terletak pada daerah optimum. Kenaikan suhu pengeringan akan menaikkan elongasi mie kering (D'Amico dkk., 2015). Sedangkan daya serap air akan meningkat dengan kenaikan suhu pengeringan. Penurunan lama pengeringan akan menaikkan kadar air dan cooking loss. Gambar 4 menunjukkan bahwa kondisi optimum tercapai pada rentang suhu 70 sampai $87^{\circ} \mathrm{C}$. Sedangkan rentang lama pengeringan terbaik adalah 3,25 jam sampai 3,9 jam. Namun demikian, tidak semua kombinasi antara suhu pengeringan dan waktu pengeringan adalah kondisi optimum. Cooking loss, kadar air dan daya serap air masuk didalam kisaran batas atas dan batas bawah. Sedangkan elongasi masuk dalam batas bawah saja (60).

\section{Optimasi Kondisi Pengeringan pada Lama Pengeringan Konstan}

Penurunan jumlah lapisan mie akan menurunkan kadar air mie kering (Gambar 5). Hal ini disebabkan semakin tebal lapisan bahan maka semakin tinggi jumlah total air yang dikandungnya, dan dengan demikian jumlah energi panas yang terkandung semakin tinggi, sehingga semakin lama waktu yang dibutuhkan untuk menghilangkan air dari bahan tersebut (Ezeanya dkk., 2016). Sedangkan cooking loss akan meningkat dengan penurunan tebal lapisan pada suhu rendah $\left(<80^{\circ} \mathrm{C}\right)$. Pada suhu tinggi cooking loss akan menurun (Gambar 5). Elongasi mie kering terletak pada daerah optimum. Sedangkan daya serap air lebih besar dari 150\%. Gambar 5 menunjukkan bahwa kondisi optimum tercapai pada rentang suhu 76 sampai $85^{\circ} \mathrm{C}$. Sedangkan jumlah lapisan mie adalah 2 lapisan. Cooking loss, kadar air dan daya serap air masuk didalam kisaran batas atas dan batas bawah. Sedangkan elongasi masuk dalam batas bawah saja (60).

\section{KESIMPULAN}

Pengeringan mie singkong dalam kabinet dryer pada suhu tinggi dapat menurunkan kadar air sesuai dengan kadar air mie dalam SNI. Kisaran suhu kondisi optimum pengeringan adalah pada suhu 76 sampai dengan $84{ }^{\circ} \mathrm{C}$ dengan lama pengeringan 3,2 sampai 3,5 jam dan mie disusun 2 lapis. Mie singkong kering mempunyai nilai elongasi 60 sampai dengan $70 \%$, kadar air 8 sampai dengan $9 \%$, Cooking loss 10 sampai dengan $12 \%$ dan daya serap air 140 sampai dengan $150 \%$. Secara umum dapat dilihat bahwa pengeringan mie pada suhu tinggi dapat mengurangi cooking loss dan memperpendek lama pengeringan. 


\section{UCAPAN TERIMA KASIH}

Ucapan terima kasih disampaikan kepada Direktorat Riset \& Pengabdian Masyarakat Direktorat Jendral Penguatan Riset dan Pengembangan, Kementerian Riset, Teknologi dan Pendidikan Tinggi yang telah memberikan bantuan dana penelitian melalui Penelitian Produk Terapan sesuai dengan kontrak No.109/SP2H/ LT/DRPM/2018.

\section{KONFLIK KEPENTINGAN}

Penulis menyatakan bahwa data dalam paper ini asli dan belum pernah dipublikasikan, serta tidak ada konflik kepentingan.

\section{DAFTAR PUSTAKA}

AACC. (2000). Approved methods of the American Association of Cereal Chemists. 10th edn. St.Paul, Minnesota.

AOAC. Association of Official Analytical Chemist. (2005). Official Method of Analysis. $18^{\text {th }}$ edition.Association of Official Analytical Chemist. Washington DC, USA.

Bai, Y. P., Guo, X. N., Zhu, K. X., dan Zhou, H. M. (2017). Shelflife extension of semi-dried buckwheat noodles by the combination of aqueous ozone treatment and modified atmosphere packaging. Food Chemistry 237: 553-560. DOI:10.1016/j.foodchem.2017.05.156

Brennan, J. G. (2006). Evaporation and Dehydration. In: Food Processing Handbook Food Processing Handbook, James G. Brennan (Ed.), WILEY-VCH Verlag GmbH \& Co. KGaA, Weinheim, 71-124.

D'Amico, S., Maschle, J., Jekle, M., Tomoskozi, S., Lango, B., Schoenlechner, R. (2015). Effect of high temperature drying on gluten-free pasta properties. LWT - Food Science and Technology 63: 391-399. DOI: 10.1016/j. Iwt.2015.03.080

Demiray, E. dan Tulek, Y. (2014). Drying characteristics of garlic (Allium sativum L) slices in a convective hot air dryer. Heat Mass Transfer. 50:779-786. DOI: 10.1007/ s00231-013-1286-9

Ezeanya, N. C., Egwuonwu, C. C., Istifanus, A. B., dan Okafor, V. C. (2016). Determination of thin-layer solar drying kinetics of cassava noodles (tapioca). Agricultural Engineering International, 5(8): 352-360.

Inglet, G. E., Peterson, S. C., Carrier, C. J., dan Maneepun, S. (2005). Rheological, textural and sensory properties of Asian noodles containing an oat cereal hydrocolloid. J. Food Chem 90: 1-8. DOI: 10.1016/j. foochem.2003.08.023

Jeong, S., Kim, M., Yoon, M., dan Lee, S. (2017). Preparation and characterization of gluten-free sheeted doughs and noodles with zein and rice flour containing different amylose contents. Journal of Cereal Science 75: 138142. DOI: $10.1016 /$ j.jcs.2017.03.022

Kang, M. J., Bae, I. Y., dan Lee, H. G. (2018). Rice noodle enriched with okara: Cooking property, texture, and in vitro starch digestibility. Food Bioscience 22: 178-183. DOI: $10.1016 /$ j.fbio.2018.02.008

Kongkiattisak, Pisut dan Songsermpong, S. (2012). Effect of temperature and velocity of drying air on kinetics, quality and energy consumption in drying process of rice noodles. Kasetsart J. (Nat. Sci.) 46: $603-619$.

Liu, Q., Zhu, X. G. K. X. (2019). E $\square$ ects of frozen storage on the quality characteristics of frozen cooked noodles. Food Chemistry 283: 522-529. DOI: 10.1016/j. foodchem.2019.01.068

Lü, Y. G., Chen, J., Li, X. Q., Ren, L., He, Y. Q., dan Qu, L. B. (2014). Study on processing and quality improvement of frozen noodles. LWT - Food Science and Technology 59: 403-410. DOI: 10.1016/j.Iwt.2014.05.046

Mamat, K. A. Yusof, M. S. Hassan S. dan Yusoff, W. F. W. (2016). temperature and humidity determination for dried instant noodle drying machine. ARPN Journal of Engineering and Applied Sciences, 11(12): 7853-7857.

Novita I., Diki N. S., dan Nur K. I. M. (2015). Perbandingan penggunaan tepung ubi kayu dari umur panen yang berbeda dan penambahan tepung jagung dalam pembuatan mi kering. PANGAN, 24(1): 63-74. DOI: 10.33964/jp.v24i1.43

Ogawa, T., Kobayashi, T., Adachi, S. (2012). Prediction of pasta drying process based on a thermogravimetric analysis. Journal of Food Engineering 111: 129-134.

Omeire, G. C., Nwosu, J. N., Kabuo, N.O., dan Nwosu M. O. (2015). cooking properties and sensory evaluation of enriched cassava/wheat noodles. International Journal of Innovative Research in Technology \& Science (IJIRTS), 3(2): 46-50. DOI: 10.1016/j.jfoodeng.2012.01.011

Petitot, M,. Boyer, L., Minier, C., Micard, V. (2010). Fortification of pasta with split pea and faba bean flours: Pasta processing and quality evaluation. Food Research International 43: 634-641. DOI: 10.1016/j. foodres.2009.07.020

Piwińska, M., Wyrwisz, J., Kurek, M.A., and Wierzbicka,A. 2016. Effect of drying methods on the physical properties of durum wheat pasta. CYTA - JOURNAL OF FOOD, 14(4): 523-528. DOI: 10.1080/19476337.2016.1149226

Yu, X., Wang, Z., Zhang, Y., Wadood, S.A., dan Wei, Y. (2018). Study on the water state and distribution of Chinese dried noodles during the drying process. Journal of Food Engineering 233: 81-87. DOI: $10.1016 / \mathrm{j}$. jfoodeng.2018.03.021

Zhang, L., \& Nishizu, T., Hayakawa, S., Nakashima, R., \& Goto, K. (2013). Effects of different drying conditions on water absorption and gelatinization properties of pasta. Food Bioprocess Technol, 6, 2000-2009. DOI: 10.1007/ s11947-012-0976-5 